\title{
Impact of the Global Financial Crisis on the Business Cycle in the Visegrad Group
}

\author{
Bartosz Pawęta
}

\section{A B S T R A C T}

Objective: The aim of the research was to analyse morphological changes in the Visegrad Group business cycles before and after the global financial crisis of 2007/2008, and to provide comparison of their overall economic performance in terms of the real GDP growth, unemployment rate changes and price stability.

Research Design \& Methods: Visegrad Group's business cycles were determined by employing Hodrick and Prescott filter to extract cyclical fluctuations, while Bry and Boschan algorithm was applied to identify the turning points of the cycles. Morphological features of business cycles were examined. The analysis was supplemented by examining unemployment rate and price stability.

Findings: The financial crisis resulted in the drop of the GDP growth and a periodical increase in unemployment. Nevertheless, in the 20 analysed years the unemployment rate tends to attain lower values, while prices become more stable. The last two economic cycles resulted in post-crisis rebound of the GDP growth. At the same time, the performance of the countries (except for outperforming Poland) becomes more and more correlated.

Implications \& Recommendations: The Visegrad Group was affected by the crisis and it is plausible that any future disturbances in the world economy might affect it again. Further research aiming at deeper understanding of how a particular country was affected could help mitigate a negative impact of future crises.

Contribution \& Value Added: The article helps to understand how the crisis affected the V4 economies in terms of the real GDP growth, unemployment rate and price stability. It indicates how the economic aggregates behaved before and after the crash.

\begin{tabular}{ll}
\hline Article type: & research paper \\
Keywords: & economic cycle; business cycle; Visegrad Group; financial crisis \\
JEL codes: & F44
\end{tabular}

Received: 27 December $2018 \quad$ Revised: 30 January $2018 \quad$ Accepted: 17 May 2018

\section{Suggested citation:}

Pawęta, B., (2018), Impact of the Financial Crisis on business cycle in the Visegrad Group. Entrepreneurial Business and Economics Review, 6(3), 43-58. https://doi.org/10.15678/EBER.2018.060303 


\section{INTRODUCTION}

On September 15th 2008, the article on the front page of The Wall Street Journal announced: 'Crisis on Wall Street', 'The American financial system was shaken to its core'. It was one of the most memorable dates of the 2007/2008 financial crisis which made not only the American investment banks struggle for survival but also had a spillover effect on the entire economy. According to The National Bureau of Economic Research (NBER), almost $40 \%$ of the American households suffered from either unemployment, arrears on their mortgage payments, or even foreclosure. What is more, one quarter of the population in their fifties lost more than $35 \%$ of their retirement savings (Hurd, Rohwedder, 2010). These figures clearly show that millions of people suffered because of the crisis. Some lost their jobs, wages went down, prices of assets (real estate, equities) dropped, life savings perished.

In the era of globalisation there are various channels through which shocks are spread from one country to another. The contagion effect (Rigobon, 2001), which had been observed several times in the history (e.g. the Debt crisis in 1982, the Mexican Tequila effect in 1994, the Asian Flu in 1997, the Russian Cold 1998, the Brazilian Sneeze in 1999, and the NASDAQ Rash in 2000), took its toll also in the 2007/2008 financial crisis, affecting both financial markets and the real economy. On September 22nd 2008, US Forbes headline said 'Financial Crisis Goes Global'. It meant that the financial crisis had become a real problem to the people worldwide. Undoubtedly, understanding the phenomenon is of utmost importance to many researchers around the globe. Questions have been raised on how global crisis affected local economies. Understanding the economic performance before the crisis could help us identify the next crisis coming. Knowing effects it may bring could help us prepare for the next economic slowdown. The cyclical nature of economy suggests a crucial question about the behaviour of the economic (business) cycle, namely: 'How did the global financial crisis affect the economic cycle?' In this article the question will be answered taking into account the Visegrad Group (known as the "V4" and composed of Czech Republic, Hungary, Poland, Slovakia).

The aim of this article is to: (1) analyse morphological changes in the V4's business cycles both in pre- and post-crisis periods and (2) provide comparison of the overall economic performance before and after the crisis both on the Visegrad Group level as well as on the country level.

For this, Visegrad Group's business cycles will be determined using Hodrick and Prescott filter and Bry and Boschan algorithm. Next, their morphological features will be examined. As the economic cycles are usually measured by changes in national output, in order to have broader understanding of the overall economic performance, the analysis will be supplemented by the assessment of the labour market and price stability.

The plausible outcome of the article could help understand how the crisis affected the V4 economy in terms of GDP growth, unemployment rate and price stability. It might indicate how the economic aggregates behaved before and after the crash. Possibly, the results might suggests reasons for different (better/worse) economic performance of individual countries. The article is organised in the following way. Firstly, general overview 
of economic cycles theories and the latest findings in that field related to the V4 economies are summarised. Secondly, methodology and data employed in the research are explained. Thirdly, results are presented and followed by discussion and conclusions.

\section{LITERATURE REVIEW}

Economic fluctuations have fascinated researchers for centuries. From the first official announcement of the existence of fluctuations, made by Clement Juglar in 1860 and Stanley Jevons who compared economic fluctuations with sunspot cycles (see Marczak \& Piech, 2009), through some of the most famous economists of the 20th and 21st century. It was J.M. Keynes whose theories become fundamentals for economy stabilising methods and who employed aggregates as variables in economic models. His revolutionary works led to establishing a new school of economic thought called Keynesian economics, developed by P. A. Samuelson and J. R. Hicks, who proposed the theory of multiplier-accelerator model (see Jakimowicz, 2005, pp. 21-47; pp. 62-88). Together with ideas presented by Smithies (Smithies, 1966) and Goodwin (Goodwin, 1951), they form a group of so-called endogenous concepts of economic cycles.

These concepts, although significantly influencing current research of the subject, had some imperfections - e.g. they failed to fully explain simultaneous occurrence of high inflation and high unemployment in the 1970's (see Barczyk \& Kowalczyk, 1993, p. 45). This led to the emergence of other (so-called exogenous) concepts. For instance, according to Lucas's Equilibrium Theory of Business Cycle, the elasticity of prices and wages allows the economy to stabilise itself at the full employment level almost immediately. The reasons for fluctuations are unexpected or coincidental money shocks caused by the state, and a delay in information dissemination (Lucas, 1975). Monetary policy of the state is of great power (Friedman \& Schwartz, 1963) and causes disproportions between supply and demand in the market through the bank loan (see: overinvestment theory by Hayek and Mises in Barczyk, 2006, pp. 65-68). They claim that the state should not stimulate consumption in the age of a crisis, but it should try to minimise the impact of the monetary policy on the economy, preferably while the economy is still in its growth phase. Moreover, the more rapid and long economic expansion is, the more dramatic slowdown it will be followed by. This idea leads to the financial instability theory (see Minsky \& Kindleberger in Marczak \& Piech, 2009), according to which so-called Minsky's moment occurs when highly indebted market participants suddenly are no longer able to pay back their loans. What is more, the economy of a country (or countries, e.g. emerging markets) is in growth phase, foreign capital flows into that economy making it expand faster. Minsky calls such rapid growth 'the euphoric economy', which suggests even greater frailness of the system. When the first fracture of the system is observed, the foreign capital is withdrawn from the economy causing its collapse (Minsky, 1982).

The theories mentioned above have become the foundation for further investigation of the cyclical nature of economy. Nowadays, empirical analyses of the phenomenon are conducted across all geographies. A systematic approach to the subject was adopted by Barczyk (1993, 2006), Jakimowicz (2005), Marczak and Piech (2009). Sectorial analysis of the Polish economy was conducted by e.g. Skrzypczyńska (2013) who found out that cycles in the Polish economy last for approximately 3.5-4.5 years and are of various amplitudes. Slightly different results were obtained by Lenart, Mazur 
and Pipien (2016), who stated that the length of the cycle varies from 2 to 3.5 years. The latter authors also claim that morphological features of the business cycles in Poland (especially frequencies) have not changed due to the crisis.

Cross-country analyses with respect to globalisation and crisis effects on the business cycles in the region have been already conducted. Pacześ (2015) claims that business cycles in the Visegrad Group countries differ despite the close geographical location. They are often driven by political decisions. Tvrdon (2011) investigated the impact of the crisis on the labour market and observed an increase in unemployment in the most EU Member States (especially in the group of low-skilled labour force with pre- and primary education). Spectral analysis was conducted by Kijek (2017) who indicated that although the V4 countries may cooperate on the political level, they are rather competitors in the field of economy. Synchronisation investigated by Janus and Beck (2014), as well as Hanus and Vacha (2015) indicated that the Visegrad countries are well-synchronised and their cycles last for 2-4 years.

The study of the V4 contains another interesting element. On January 1st 2009 , one of its members, Slovakia, adopted euro as its currency. This allowed to raise a series of very important questions in terms of impact of flexible exchange rate and monetary policy. Some studies have shown that the exchange rate flexibility in Poland contributed to the absorption of real shocks (Dąbrowski \& Wróblewska, 2016). The comparison of the V4 performance in the last decades leads to the conclusion that adopting euro is nothing but political will (Carroll, 2012).

\section{MATERIAL AND METHODS}

\section{Aim}

The aim of this article is to:

1. Analyse morphological changes in the Visegrad Group's business cycles before and after the crisis.

2. Provide comparison of the overall economic performance before and after the crisis both on the Visegrad Group level as well on the country level.

\section{Definitions}

Fluctuations of economy defined as economic (or business) cycles are just one type of fluctuations, when classifying them according to their time span (see Rekowski, 1997, pp. 18-19). Based on that criterion, we may define: development trend, periodic fluctuations, random fluctuations and economic fluctuations. Clearly, there is no strict division between each type of fluctuations. It is also difficult to define which of the economic fluctuations can be defined as cyclical. Economists argue about what should be the length of the cycle, its phases, and regularity. So far, the unquestioned statement is that a cycle is a consecutive positive and negative relative change in a process.

Classical definition of the cycle was proposed by Burns and Mitchell (1946): 'Business cycles are a type of fluctuations found in the aggregate economic activity of nations that organise their work mainly in business enterprises'. The cycle consists of expansion phase occurring simultaneously in many economic activities, which is followed by general recession, contraction, and finally revival which leads to expansion phase of the next cycle. This definition was modified by Mintz (1972), who introduced the term 
'growth cycle', which defines phases of the cycle depending on the deviation of empirical value of an economic indicator (e.g. GDP) from its estimated trend line. In such a cycle, two phases are distinguished, namely: period of relatively high growth rates, and period of relatively low growth rates. In analysis, so called deviation cycle is often constructed. For analysis in this article the following definition is adopted: Economic cycle - systematic changes of general economic activity oscillating around a long-term trend. The economic activity is measured by absolute or relative changes in time of main economic indicators, preferably Gross Domestic Product (Barczyk, 2006).

Other definitions used in this article include (Barczyk \& Kowalczyk, 1993; Pangsy-Kania, 2004):

1. Turning points - upper and lower turning points are distinguished. The upper are called peak' or 'downturn', while the lower are called 'trough' or 'upturn'. On that basis, it can be stated that a cycle is the time span between two consecutive turning points of the same type.

2. Phase - based on the identification of turning points, cycle phases can be defined as the time span between two consecutive, but opposite, turning points. In modern cycles, often two phases are distinguished only. These are periods of relatively high growth rates, and periods of relatively low growth rates (originally referring to the growth cycle by Mintz, 1972).

3. Length (or duration) - both the length of the cycle as well as the length of its phases can be determined. The length of a phase is its duration in time. Obviously, the length of a cycle is its time duration in time, being equal to the sum of durations of all its phases.

4. Amplitude - it refers either to a phase or the cycle. The amplitude of a phase is equal to the absolute value of the difference between value that the phase attains at its maximum and minimum. In other words, it is the absolute value of the difference between values attained at the turning points of the phase. The amplitude of a cycle is defined as the difference between the amplitude of the growth phase and the amplitude of the decline phase.

5. Intensity - measures the strength of growth or decline in each phase, or the whole cycle. The tool used in this procedure is the standard deviation of data series. The higher value of the standard deviation is, the more intensive the cycle is.

\section{Data}

Data used in the research are:

1. Real Gross Domestic Product (GDP) changes quarter to quarter of previous year. The time span covers the period 1996Q1-2017Q3. This economic aggregate will be employed in the business cycle analysis.

2. Consumer Price Index (CPI). The time span covers the period 1996Q1-2017Q3. Employing this indicator will allow to observe how economic growth/decline corresponded to price changes in economy.

3. Unemployment rate. The time span covers the period 1996Q1-2017Q2, however, as some data-points are missing, the full set of data is available only since 1999Q4.

Unemployment level, together with GDP and CPI, provides the overall description of the economic situation in a given point in time. Data were retrieved from the Organisation 
for Economic Co-operation and Development (OECD) online database on 05th Dec 2017 and for countries forming the Visegrad Group (V4), namely: the Czech Republic, Hungary, Poland and Slovakia.

\section{Methodology}

The research is based on the morphological analysis of the Visegrad Group's business cycles. For this, the V4 business cycle was constructed from data for individual countries. One of the methods used in decomposition of the time series is to apply filters, such as Baxter and King (1999), Hodrick and Prescott (1997) or Christiano and Fitzgerald (1999). In this article real GDP change $Q /(Q-4)$ data were employed to construct deviation cycle using Hodrick and Prescott filter with the parameter $\lambda=1600$.

In order to determine turning points, and consequently phases, the algorithm developed by Bry and Boschan (1971) was used:

1. The peak (trough) of the cycle is attained in the quarter $t$, if the value of the cycle in the preceding and the following quarter is lower (higher) than in the quarter $t$;

2. Each phase of the cycle must be at least 2 quarters long;

3. The length of the cycle cannot be shorter than 5 quarters;

4. When a given cycle ends, another one starts.

Furthermore, additional criteria were adopted, as in the case of modern cycles it might be problematic to precisely indicate the occurrence of turning points as they often are so-called turning zones (Barczyk \& Kowalczyk, 1993):

1. They cannot be identified at the end of the analysed series, unless data from the following time periods confirms that it is justified;

2. In case of double-top (double-bottom), turning point is identified the second peak (trough), after which decline (growth) is observed;

3. If the analysed cycle attains its maxima (minima), but it is impossible to precisely indicate the turning point, as similar values occur for several time periods, then the turning point is identified at the end of this period, after which change in values is observed.

As a supplementary analysis, the assessment of CPI and unemployment levels is made, their behaviour before and after the crisis analysed and correlations between the V4 countries determined. Post-crisis period is defined as the one starting one quarter after the end of the decline phase caused by the crisis.

\section{RESULTS AND DISCUSSION}

\section{Business Cycle Analysis}

In the time interval analysed, seven business cycles in the Visergad Group economy were identified (Figure 1). The point in time when cycle number 5 ends (2009-Q2) is the quarter when the average GDP growth rate in the V4 reached its minimal value after the crisis. In 2009-Q3 the post-crisis recovery started.

The average length of the cycles observed is equal to 2.75 years (see Table 1 ) which is in line with the results obtained by Lenart, Mazur and Pipien (2016). The two post-crisis cycles (number 6 and 7) lasted slightly longer with their length of 3.5-3.75 years, which corresponds to the results presented by Skrzypczyńska (2012). The results are also similar to those obtained 
by Janus and Beck (2014), as well as Hanus and Vacha (2015). Even if we treated cycles 3 and 4 as extraordinary (very rapid economic growth just before the crash) and do not include them in the observations, post-crisis cycles are longer than those which occurred until 2002-Q2.

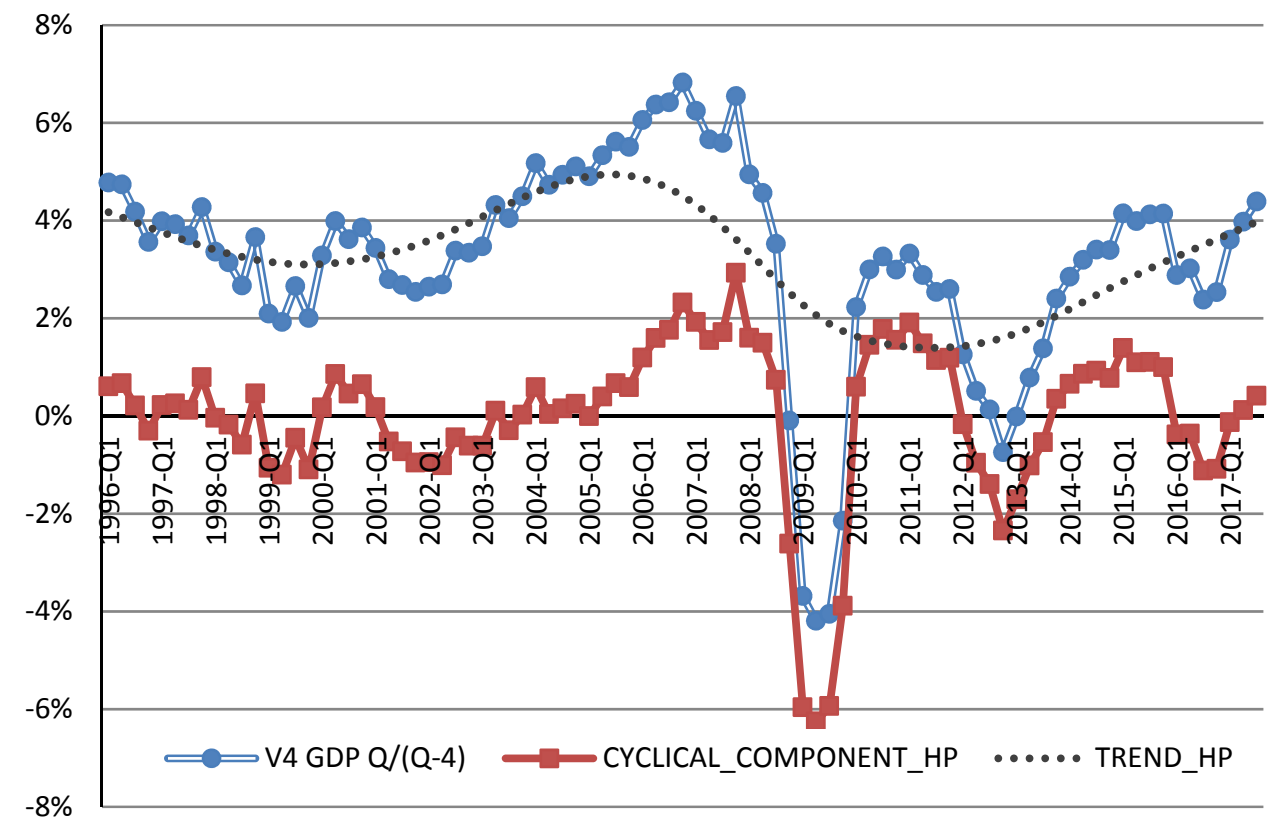

Figure 1. Economic fluctuations in the Visegrad Group in the years 1996-2016 V4 GDP Q/(Q-4) - real GDP growth quarter to quarter previous year TREND_HP - trend line estimated with the Hodrick and Prescott filter CYCLICAL COMPONENT_HP - deviation from the HP trend line Source: own calculations based on OECD data.

The average length of the cycles observed is equal to 2.75 years (see Table 1 ) which is in line with the results obtained by Lenart, Mazur and Pipien (2016). The two post-crisis cycles (number 6 and 7) lasted slightly longer with their length of 3.5-3.75 years, which corresponds to the results presented by Skrzypczyńska (2012). The results are also similar to those obtained by Janus and Beck (2014), as well as Hanus and Vacha (2015). Even if we treated cycles 3 and 4 as extraordinary (very rapid economic growth just before the crash) and do not include them in the observations, post-crisis cycles are longer than those which occurred until 2002-Q2.

Although within each cycle, the number of growth and decline quarters differ (consequently, the cycles are not symmetrical with respect to the length of their phases), in the time span covered by seven cycles (79 quarters from 1996-Q4 to 2016-Q3) there is almost equal proportion of growth and decline quarters ( 40 growth, 39 decline). In the post-crisis cycles there is natural higher amplitude observed, which is the result of the rebound after a sharp decline of the GDP growth in cycle 5 . Since that time, both post-crisis cycles have positive amplitudes. They also have higher intensity indicating that the oscillations around the trend line after the crisis diverge from the trend line more than they used to do. High diver- 
Table 1. Morphological analysis of the Visegrad Group business cycles in the years 1996-2016

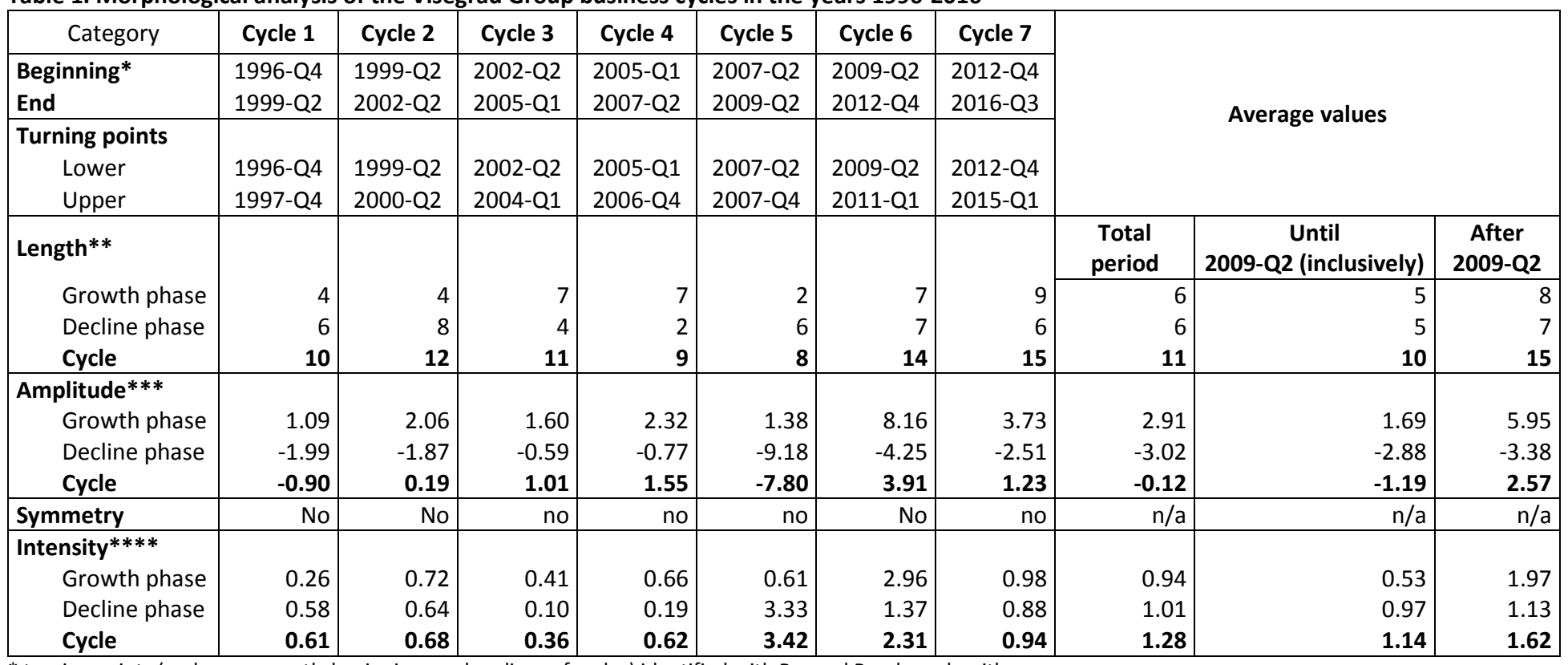

* turning points (and consequently beginnings and endings of cycles) identified with Bry and Boschan algorithm

** measured in the number of quarters

$* * *$ measured in percentage points

$* * * *$ standard deviation of the cyclical component

Source: own calculations based on the research results. 
gence from the trend line might confirm the observation by Brender and Drazen (2005) that economic fluctuations are more volatile in relatively young democracies (such as the V4).

\section{Overall Economic Performance Analysis}

The real GDP growth of the Visegrad Group was on average 1.5 percentage points lower in the post-crisis period (see Table 2), even though the average value until 2009-Q2 contains negative impact of the crisis itself (which is the decline phase of cycle 5). In fact, since the beginning of the time series analysed (1996-Q1) until 2008-Q4 there was no decline in the real GDP observed in the total Visegrad Group performance. The rapid growth in that time was mainly driven by an increase in productivity, increasing trade with the European Union, and high entrepreneurial potential in that region (Pawęta, 2013). For the V4 Group, only the 5th economic cycle's decline phase brought severe economic slowdown. Negative yearly real GDP change occurred for 5 quarters in a row and reached a minimum of $-4.2 \%$. Another drop below the $0 \%$ growth line, which however did not attain as dramatically low values, occurred in the winter of 2012/2013.

Among the Visegrad Group countries it is Slovakia which faced the sharpest drop in the average GDP growth (Figure 2). Interestingly, before the post-crisis period it grew at the fastest pace among the V4 countries (on average $4.8 \%$ per year), but since 2009-Q3 the average growth was lower by 2.3 percentage points. This might confirm the overinvestment theory by Hayek and Mises (in Barczyk, 2006, pp. 65-68) which says that the more rapid and long economic expansion is, the more dramatic slow-down it will be followed by. High growth before the crisis could have supported the political decision of entering the euro area (Carroll, 2012). The drop, however, possibly confirms also the results obtained by other researchers claiming that Slovakia lacked its monetary policy and the exchange rate which could act like a shock absorber and could help mitigate the impact of the crisis as in those countries which did not adopt euro as their currency (Dąbrowski \& Wróblewska, 2016; Konopczak \& Marczewski, 2011).

The GDP growth of Poland on the other hand was the 2nd fastest after Slovakia before the post-crisis period, while in the post-crisis period it managed to maintain the highest average GDP growth of all V4 members. Poland, where there was no enough political will to enter the euro area, never faced the recession in the whole time span analysed. The economy of Poland performed well also because of a lower degree of openness and resilience of internal activity (Konopczak \& Marczewski, 2011).

Hungarian and the Czech Republic's average GDP growth rates were quite similar in both time intervals. In both cases it was also lower than the V4 average. This is due to the fact that the Czech Republic was dependent on the external demand, while Hungary faced problems in the banking sector (Tvrdon, 2011). Hungary was also the least correlated member of the V4 with respect to its average GDP growth before the post-crisis period. In fact, only Slovakia and the Czech Republic were fairly correlated. This might be the result of their 75 year economic relations as Czechoslovakia (Kijek, 2017). In general, the average correlation of the V4 member states with V4 average might seem low (corr. coef. $=0.68$ ), as the V4 countries have a lot in common: they are post-Soviet countries, they formed the Visegrad Group back in 1991, they joined the European Union together in 2004. Their economic cooperation, however, is relatively low. They rather seem to compete with each other as they try to attract foreign capital and increase their export size (Kijek, 2017). After the crisis all correlation coefficients increased (average corr. coef. $=0.82$ ). This might be 
the result of either joining the EU as their synchronisation with the EU also increases (Konopczak \& Marczewski, 2011; Hanus \& Vacha, 2015) or facing similar problems on their rebound path after the crisis. Increasing correlation might also be in line with the theory of Optimum Currency Area (Mundell, 1961) which claims that in order to form a successful currency area, business cycles of its individual members must be synchronised. Of all V4

Table 2. Comparison of overall economic performance of the Visegrad Group countries and their correlation before the crisis and in the post-crisis period

\begin{tabular}{|c|c|c|c|c|c|c|}
\hline Average growth of real GDP Q/(Q-4) & CZE & HUN & POL & SVK & Average & Median St. Dev. \\
\hline Until 2009-Q2 (inclusively) & $3.1 \%$ & $2.8 \%$ & $4.5 \%$ & $4.8 \%$ & $3.8 \%$ & $4,0 \%$ \\
\hline After 2009-Q2 & $1.7 \%$ & $1.5 \%$ & $3.2 \%$ & $2.5 \%$ & $2.3 \%$ & $2.9 \%$ \\
\hline Change & $-1.3 \%$ & $-1.3 \%$ & $-1.3 \%$ & $-2.3 \%$ & $-1.5 \%$ & $-1.1 \%$ \\
\hline Country correlation to average V4 & CZE & HUN & POL & SVK & Average & Median St. Dev. \\
\hline Until 2009-Q2 (inclusively) & 0.82 & 0.57 & 0.49 & 0.82 & 0.68 & $0.70 \quad 0.15$ \\
\hline After 2009-Q2 & 0.96 & 0.89 & 0.58 & 0.86 & 0.82 & 0.88 \\
\hline Change & 0.13 & 0.32 & 0.09 & 0.04 & 0.14 & 0.18 \\
\hline Cross-country correlation & $\begin{array}{l}\text { CZE- } \\
\text { HUN }\end{array}$ & $\begin{array}{l}\text { CZE- } \\
\text { POL }\end{array}$ & $\begin{array}{l}\text { CZE- } \\
\text { SVK }\end{array}$ & $\begin{array}{l}\text { HUN- } \\
\text { POL }\end{array}$ & $\begin{array}{l}\text { HUN- } \\
\text { SVK }\end{array}$ & $\begin{array}{l}\text { POL- } \\
\text { SVK }\end{array}$ \\
\hline Until 2009-Q2 (inclusively) & 0.41 & 0.24 & 0.58 & 0.01 & 0.23 & 0.27 \\
\hline After 2009-Q2 & 0.81 & 0.55 & 0.78 & 0.34 & 0.68 & 0.31 \\
\hline Change & 0.40 & 0.32 & 0.20 & 0.33 & 0.46 & 0.04 \\
\hline Average Consumer Price Index value & CZE & HUN & POL & SVK & Average & Median St. Dev. \\
\hline Until 2009-Q2 (inclusively) & $4.3 \%$ & $9.3 \%$ & $6.4 \%$ & $6.2 \%$ & $6.5 \%$ & $5.5 \% \quad 3.8 \%$ \\
\hline After 2009-Q2 & $1.4 \%$ & $2.5 \%$ & $1.6 \%$ & $1.2 \%$ & $1.7 \%$ & $2.0 \%$ \\
\hline Change & $-2.9 \%$ & $-6.8 \%$ & $-4.8 \%$ & $-5,0 \%$ & $-4.9 \%$ & $-3.5 \% \quad-2.2 \%$ \\
\hline Country correlation to average V4 & CZE & HUN & POL & SVK & Average & Median St. Dev. \\
\hline Until 2009-Q2 (inclusively) & 0.81 & 0.96 & 0.97 & 0.4 & 0.79 & $0.88 \quad 0.23$ \\
\hline After 2009-Q2 & 0.81 & 0.93 & 0.96 & 0.91 & 0.9 & 0.92 \\
\hline Change & 0.00 & -0.02 & -0.02 & 0.51 & 0.12 & 0.04 \\
\hline Cross-country correlation & $\begin{array}{l}\text { CZE- } \\
\text { HUN }\end{array}$ & $\begin{array}{l}\text { CZE- } \\
\text { POL }\end{array}$ & $\begin{array}{l}\text { CZE- } \\
\text { SVK }\end{array}$ & $\begin{array}{l}\text { HUN- } \\
\text { POL }\end{array}$ & $\begin{array}{l}\text { HUN- } \\
\text { SVK }\end{array}$ & $\begin{array}{l}\text { POL- } \\
\text { SVK }\end{array}$ \\
\hline Until 2009-Q2 (inclusively) & 0.76 & 0.77 & 0.02 & 0.95 & 0.22 & 0.27 \\
\hline After 2009-Q2 & 0.65 & 0.64 & 0.80 & 0.90 & 0.72 & 0.84 \\
\hline \begin{tabular}{|l|} 
Change \\
\end{tabular} & -0.11 & -0.13 & 0.78 & -0.05 & 0.51 & 0.57 \\
\hline Average unemployment rate & CZE & HUN & POL & SVK & Average & Median St. Dev. \\
\hline Until 2009-Q2 (inclusively) & $7.3 \%$ & $6.8 \%$ & $14.3 \%$ & $14.8 \%$ & $11.2 \%$ & $11.8 \%$ \\
\hline After 2009-Q2 & $6,0 \%$ & $8.8 \%$ & $8.6 \%$ & $12.7 \%$ & $9,0 \%$ & $10.1 \%$ \\
\hline Change & $-1.2 \%$ & $2.0 \%$ & $-5.7 \%$ & $-2.2 \%$ & $-2.1 \%$ & $-1.7 \%$ \\
\hline Country correlation to average V4 & CZE & HUN & POL & SVK & Average & Median St. Dev. \\
\hline Until 2009-Q2 (inclusively) & 0.88 & -0.80 & 0.90 & 0.83 & 0.45 & $\begin{array}{ll}0.86 & 0.73 \\
\end{array}$ \\
\hline After 2009-Q2 & 0.99 & 0.97 & 0.98 & 0.98 & 0.98 & 0.98 \\
\hline Change & 0.11 & 1.78 & 0.07 & 0.15 & 0.53 & 0.12 \\
\hline Cross-country correlation & $\begin{array}{l}\text { CZE- } \\
\text { HUN }\end{array}$ & $\begin{array}{l}\text { CZE- } \\
\text { POL }\end{array}$ & $\begin{array}{l}\text { CZE- } \\
\text { SVK }\end{array}$ & $\begin{array}{l}\text { HUN- } \\
\text { POL }\end{array}$ & $\begin{array}{l}\text { HUN- } \\
\text { SVK }\end{array}$ & $\begin{array}{l}\text { POL- } \\
\text { SVK }\end{array}$ \\
\hline Before 2009-Q2 & -0.59 & 0.81 & 0.88 & -0.85 & -0.85 & 0.93 \\
\hline After 2009-Q2 & 0.96 & 0.94 & 0.97 & 0.92 & 0.93 & 0.98 \\
\hline Change & 1.55 & 0.14 & 0.1 & 1.76 & 1.77 & 0.05 \\
\hline
\end{tabular}

Source: own calculations based on the research results. 
members, until today only Slovakia has joined the euro area and naturally its business cycle has become more and more coherent with the euro zone (Hanus \& Vacha, 2015). The lowest degree of correlation with individual V4 members as well with the V4 average is noticed in the case of Poland, which is a natural consequence of Poland outperforming other V4 members in terms of the average GDP growth.

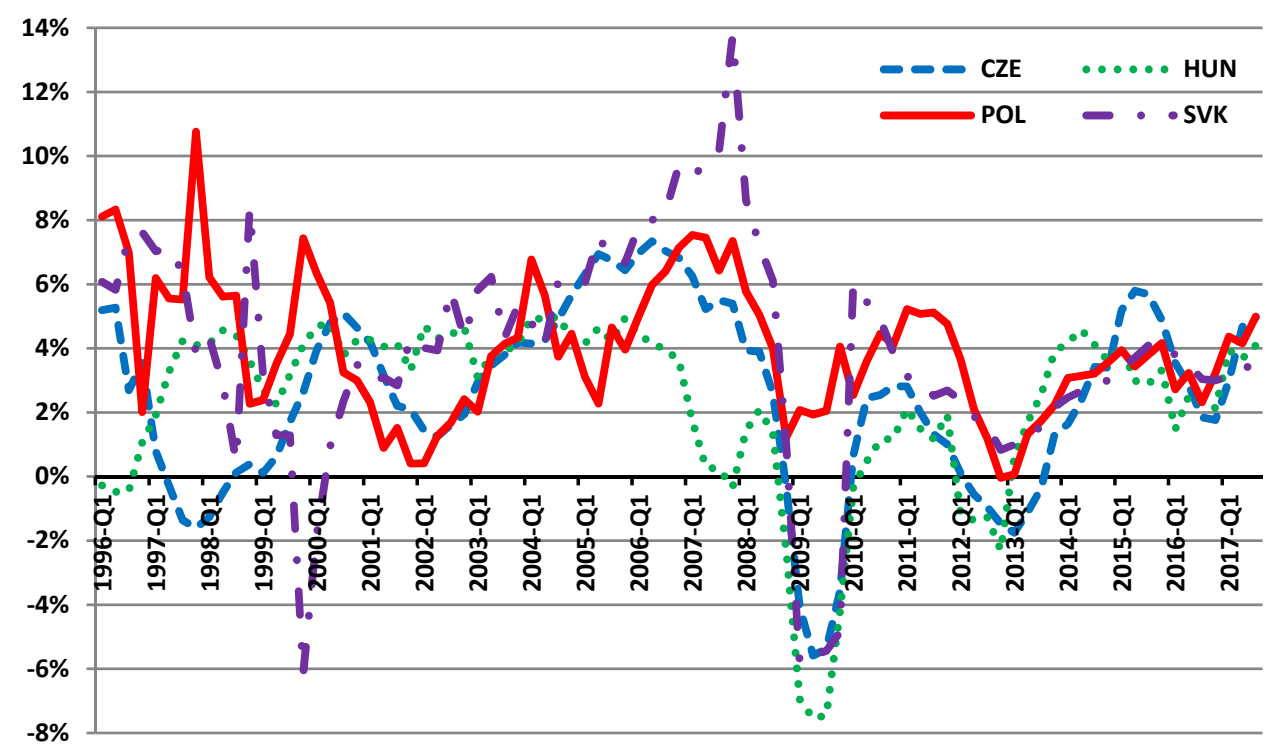

Figure 2. Real GDP growth (quarter to quarter of previous year) in the V4 countries, 1996-2016 Source: OECD

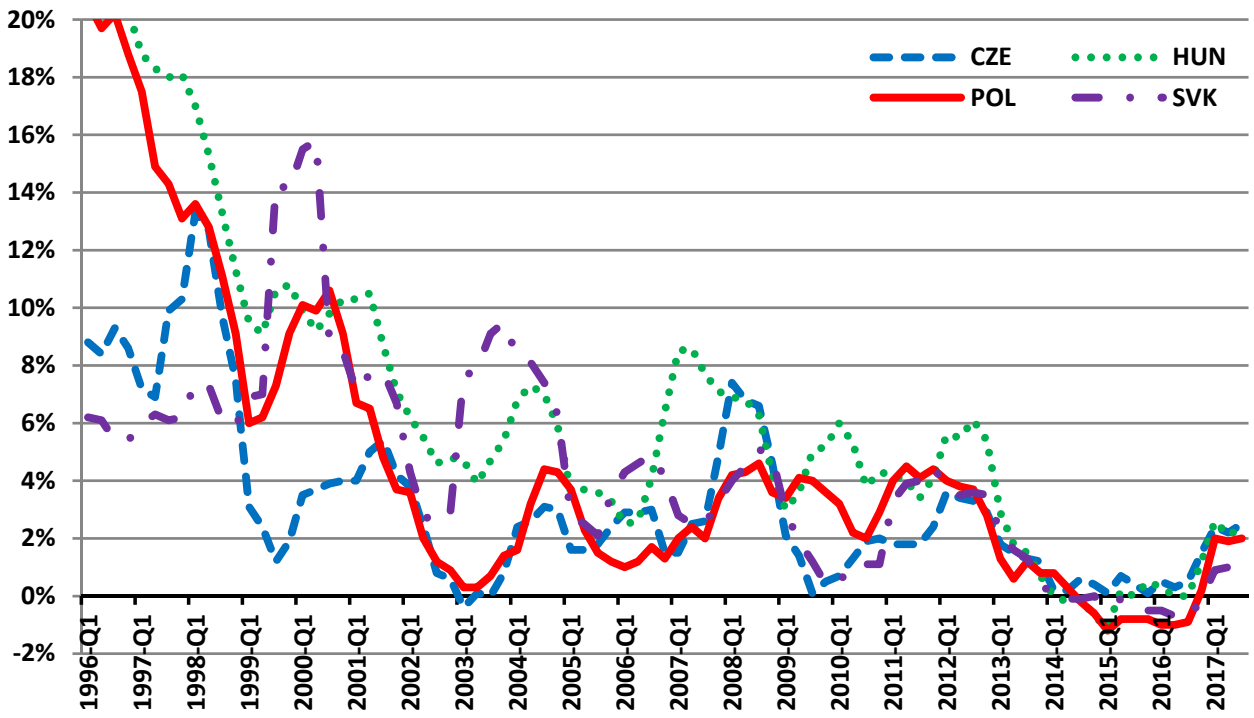

Figure 3. Consumer Price Index in the V4 countries, 1996-2016 


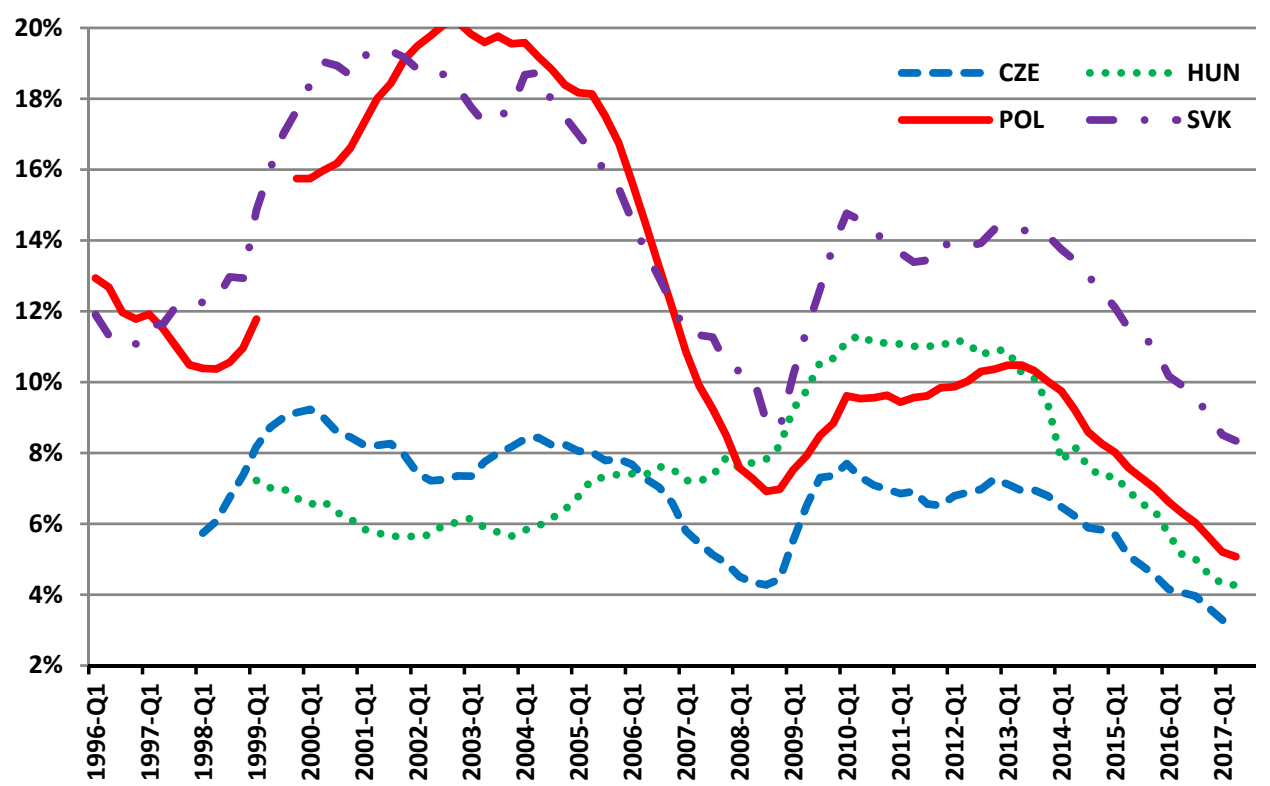

Figure 4. Unemployment rate in the V4 countries in the years 1996-2016 Source: OECD

In the time interval analysed, the price changes trend line, measured with the Consumer Price Index, was negative (Figure 3). This might be explained by a (1) drop from high level inflation that all countries suffered from after political and economic transformation, (2) improvements in the monetary/fiscal policy and (3) lower real GDP growth as a result of the financial crisis. Also CPI oscillations have become less volatile, which indicates higher stability in the economy. When compared pre- and post-crisis averages, it can be noticed that the highest drop of CPI inflation occurred in Slovakia and Hungary, which corresponds to their highest drop in the GDP growth. After the crisis, the lowest average CPI inflation was observed in the only euro area member of V4 - Slovakia. The post-crisis correlation of price changes is quite high among all V4 members.

Similarly to CPI inflation, the V4's unemployment rate trend line is on average downward-sloping in the time span analysed (Figure 4). The rate of unemployment as well as its behaviour in time differs across countries. Prior to the EU accession Slovak and Polish unemployment rates were over 2 times higher than in Hungary and the Czech Republic. After that date, a decline of the unemployment rate was observed in all the countries (except for Hungary which struggled with unstable fiscal situation) and reached its minimal value in the second half of 2008. The financial crisis resulted in the increase in unemployed rate and that number remained high until 2013, when the economic cycle number 7 started. At the end of the time series analysed all unemployment rates are on the level of around $5 \%$ or less, with only Slovak unemployment rate almost twice higher than in the rest of the V4. The results are coherent with previous research on the impact of the financial crisis on 
the labour market, while more detailed view of the labour market in the Visegrad Group was presented by Tvrdon (2011).

\section{CONCLUSIONS}

This article can help to understand how the crisis affected the V4 economy. It indicates how the economic aggregates behaved before and after the crash. A specific aim of the research was to analyse morphological changes in the Visegrad Group business cycles before and after the financial crisis of 2007/2008 and provide comparison of their overall economic performance in terms of the real GDP growth, unemployment rate changes and price stability. The analysis included both the Visegrad Group level as well as individual countries - Poland, Slovakia, Hungary and the Czech Republic.

For this, Visegrad Group's business cycles were determined. The Hodrick and Prescott filter was used to extract cyclical fluctuations, while Bry and Boschan algorithm was applied to identify turning points of the cycles. In the research morphological features of the cycles were examined. Additionally, in order to have broader understanding of the overall economic performance, the analysis was supplemented by the assessment of the labour market (by examining unemployment rate) and price stability (measured by CPI inflation).

There were seven business cycles observed in the Visegrad Group in the time span analysed (1996-2016). Each of them differed in terms of symmetry, but in the 20 year period there was equal number of growth quarters and decline quarters. What shall be underlined is that until the financial crisis, there was no GDP drop observed until 2008-Q4. In 2009-Q3 post-crisis cycles started. Their duration was longer (3.5-3.75 years), while their amplitude and intensity higher than in the pre-crisis period.

The financial crisis not only influenced morphological characteristics of the business cycle in the Visegrad Group, but also affected its overall economic performance. The real GDP growth of the V4 was on average 1.5 percentage points lower in the post-crisis period, even though the former time interval contained the crisis itself. The financial crisis seemed to have the biggest impact on Slovakia, which had the highest pace of growth before the crisis and (due to adopting euro as its currency) no flexible exchange rate and no monetary policy to mitigate crisis effects. The best economic performance was observed in Poland, where due to strong internal demand and relatively low openness, the GDP growth dropped the least, while historically high unemployment rate fell below the V4 average.

As a result of the crisis, in all V4 members an increase in the unemployment rate occurred, but it was also Slovakia where the value was almost twice higher than in the rest of the V4. Nevertheless, over the whole time span analysed, the overall trend line of unemployment rate was negative, although it differed from country to country.

The trend line of price stability was also negative, however the correlation of price changes is quite high among all V4 members.

In the case of GDP growth, unemployment rate and price stability, different levels of correlations were observed before the post-crisis period. In the post-crisis era economic performance of all countries (except Poland and its higher GDP growth) is highly correlated. It could be caused by increasing economic integration after joining the EU or facing similar problems while mitigating negative impact of the financial crisis. It also seems to be in in line with the Theory of Optimum Currency Area - in order to form a successful 
currency area, economic performance of its members should be similar. This is crucial for Hungary, Poland and the Czech Republic to join Slovakia in the euro area.

The limitation of this article is the fact that only basic economic aggregates were employed. Expanded research could include monthly data of other aggregates such as industrial production, investments, etc. It would be also recommended to use filters other than HP to determine cyclical components and compare the results. Moreover, perhaps dividing the sample into three subperiods could be considered: pre-crisis, crisis itself and post-crisis. Another limitation is the time span of the research in which only two post-crisis cycles occurred so far. Conducting similar analysis in a few years could definitely add more value to examining impact of the financial crisis on the business cycles. Further research aiming at deeper understanding of how particular country was affected could help mitigate impact of future crises.

The research indicated that through contagion effect the Visergad Group was affected by the crisis and it is plausible that any future disturbances in the world economic system might affect it again. The overall impact of the 2007/2008 financial crisis resulted in a drop in the GDP growth and periodical unemployment growth. Nevertheless, in the 20 years analysed the unemployment rate tends to attain lower values, while prices become more stable. The last two economic cycles formed a post-crisis rebound of the GDP growth. At the same time, countries performance of the countries (except for outperforming Poland) became more and more correlated. This might unite the Visegrad Group not only in terms of their common history and their political goals, but also in the field of economy.

\section{REFERENCES}

Barczyk, R. (2006). Nowe oblicza cyklu koniunkturalnego. Warszawa: PWE.

Barczyk, R., \& Kowalczyk, Z. (1993). Metody badania koniunktury gospodarczej. Warszawa-Poznań: Wydawnictwo Naukowe PWN.

Baxter, M., \& King, R.G. (1999). Measuring business cycles: approximate band-pass filters for economic time series. Review of Economics and Statistics, 81(4), 575-593. https://doi.org/10.1162/003465399558454

Beck, K., \& Janus, J. (2014). Synchronization of Economic Shocks in the Visegrad Group: An Empirical Assessment. Studia UBB Negotia, 5, 35-56.

Brender, A., \& Drazen, A. (2005). Political budget cycles in new versus established democracies. Journal of Monetary Economics, 52(7), 1271-1295. https://doi.org/ 10.3386/w10539

Bry, G., \& Boschan, C. (1971). Cyclical analysis of economic time series: selected procedures and computer programs (NBER Technical Working Paper, 20).

Burns, A.F., \& Mitchell, W.C. (1946). Measuring business cycles. New York: NBER Books.

Christiano, L.J., \& Fitzgerald, T.J. (2003). The Band Pass Filter. International Economic Review, 44(2), 435-465.

Carroll, J.M. (2011). Slovakia and the Euro: How Slovakia has Out-paced its Visegrád Neighbors on the Path to Economic and Monetary Union (Doctoral dissertation, The University of North Carolina at Chapel Hill).

Dąbrowski, M.A., \& Wróblewska, J. (2016). Exchange rate as a shock absorber in Poland and Slovakia: Evidence from Bayesian SVAR models with common serial correlation. Economic Modelling, 58, 249-262. https://doi.org/10.1016/j.econmod.2016.05.013

Friedman, M., \& Schwartz, A.J. (2008). A monetary history of the United States, 1867-1960. New York: Princeton University Press. 
Goodwin, R.M. (1951). The nonlinear accelerator and the persistence of business cycles. Econometrica: Journal of the Econometric Society, 1-17. https://doi.org/10.2307/1907905

Hanus, L., \& Vacha, L. (2015). Business cycle synchronization of the Visegrad Four and the European Union (No. 19/2015). IES Working Paper.

Hodrick, R.J., \& Prescott, E.C. (1997). Postwar US business cycles: an empirical investigation. Journal of Money, Credit, and Banking, 29(1), 1-16.

Hurd, D., \& Rohwedder, S. (2010). Effects of the Financial Crisis and Great Recession on American Households (Working Paper No. 16407). National Bureau of Economic Research.

Jakimowicz, A. (2003). Od Keynesa do teorii chaosu: ewolucja teorii wahań koniunkturalnych. Warszawa: Wydawnictwo Naukowe PWN.

Kijek, A. (2017). Spectral Analysis Of Business Cycles In The Visegrad Group Countries. Comparative Economic Research, 20(2), 53-73.

Konopczak, K., \& Marczewski, K. (2011). Why so different from other CEECs - Poland's cyclical divergence from the euro area during the recent financial crisis. Bank i Kredyt, 42(2), 7-30.

Lenart, Ł., Mazur, B., \& Pipień, M. (2016). Statistical Analysis of Business Cycle Fluctuations in Poland Before and After the Crisis. Equilibrium. Quarterly Journal of Economics and Economic Policy, 11(4), 769-783. https://doi.org/10.12775/EQUIL.2016.035

Lucas Jr, R.E. (1975). An equilibrium model of the business cycle. Journal of Political Economy, 83(6), 1113-1144. https://doi.org/10.1086/260386

Marczak, K., \& Piech K. (2009). Cykle koniunkturalne: ujęcie historyczne i przegląd głównych teorii. In Koniunktura gospodarcza. Od bańki internetowej do kryzysu subprime. Warszawa: C.H. Beck.

Minsky, H. (1982). Can 'it' happen again? Essays on instability and finance. New York: M.E. Sharpe.

Mundell, R.A. (1961). A Theory of Optimum Currency Areas. The American Economic Review, 51(4), 657-665.

Pacześ, P. (2015). Decyzje polityczne a cykl koniunkturalny w państwach inicjatywy wyszehradzkiej, Podejście krótkookresowe i strategiczne w polityce gospodarczej, Prace i materiały Instytutu Rozwoju Gospodarczego SGH, Warszawa, 75-93.

Pangsy-Kania, S. (2004). Przegląd teoretycznych aspektów cyklu koniunkturalnego. Ekonomia, 12, Wydział Nauk Ekonomicznych Uniwersytetu Warszawskiego, 109-125.

Pawęta, E. (2013). The Determinants of Born Global Companies Emergence in Central European Countries. Entrepreneurial Business and Economics Review, 1(2), 41-50. https://doi.org/10.15678/EBER.2013.010204

Rigobon, R. (2001). Contagion: How to Measure It?. (Working Paper No. 8118). National Bureau of Economic Research.

Skrzypczyńska, M. (2013). Cykl koniunkturalny w Polsce - analiza sektorowa. Bank i Kredyt, 44(2), 175-205.

Smithies, A. (1966). Economic Fluctuations and Growth, Readings in Business Cycle. London: George Allen London.

Tvrdon, M. (2011). Impacts of the global economic crisis on the European labor market performance: the case of Visegrad Group countries. Recent Advances in Business Administration, 5th WSEAS International Conference on Business Administration, Mexico, 38-44.

\section{Statistical data}

OECD. (2017). Quarterly GDP (indicator). https://doi.org/10.1787/b86d1fc8-en (Retrieved on December 5, 2017)

OECD. (2017). Inflation (CPI) (indicator). https://doi.org/10.1787/eee82e6e-en (Retrieved on December 5, 2017) 
OECD. (2017). Unemployment rate (indicator). https://doi.org/10.1787/997c8750-en (Retrieved on December 5, 2017)

\section{Other sources}

Forbes US edition. (2008). Financial Crisis Goes Global, Retrieved on December 5, 2017 from https://www.forbes.com/2008/09/19/banks-contagion-globalization-cx_0919oxford.html\#b6 525933ed9d

The Wall Street Journal. (2008). Crisis on Wall Street as Lehman Totters, Merrill Is Sold, AIG Seeks to Raise Cash, Retrieved on December 5, 2017 from https://www.wsj.com/articles/SB122139688846233147

\section{Author}

\section{Bartosz Pawęta}

MSc in Business and Technology (Technical University of Lodz, Poland), PhD researcher at the Faculty of Economics and Sociology (University of Lodz, Poland). Completed International Business and Technology Management programme (Lappeenranta university of Technology, Finland) and postgraduate studies in Corporate Finance (Warsaw School of Economics, Poland). His main research interests include economic fluctuations, specifically economic crises.

Correspondence to: Bartosz Pawęta, University of Lodz, Faculty of Economics and Sociology, UI. POW 3/5, 90-255 Łódź, Poland, e-mail: bartosz.paweta@gmail.com

\section{Acknowledgements and Financial Disclosure}

Author would like to thank the anonymous referees for their useful comments which contributed to increase the value of this article.

\section{Copyright and License}

This article is published under the terms of the Creative Commons Attribution - NoDerivs (CC BY-ND 4.0) License http://creativecommons.org/licenses/by-nd/4.0/

Published by the Centre for Strategic and International Entrepreneurship - Krakow, Poland 